\title{
Water ferns Azolla spp. (Azollaceae) as new host plants for the small China-mark moth, Cataclysta lemnata (Linnaeus, 1758) (Lepidoptera, Crambidae, Acentropinae)
}

\author{
Atousa Farahpour-Haghani ${ }^{1,2}$, Mahdi Hassanpour ${ }^{1}$, Faramarz Alinia $^{2}$, \\ Gadir Nouri-Ganbalani ${ }^{1}$, Jabraeil RAZMJOU ${ }^{1}$, David Agassiz ${ }^{3}$ \\ 1 University of Mohaghegh Ardabili, Faculty of Agriculture and Natural Resources, Department of Plant Protection, \\ Ardabil, Iran \\ 2 Rice Research Institute of Iran (RRII), Agricultural Research, Education and Extension Organization (AREEO), Rasht, Iran \\ 3 Department of Life Sciences, Natural History Museum, London SW7 5BD, England \\ http://zoobank.org/307196B8-BB55-492B-8ECC-1F518D9EC9E4
}

Received 1 August 2016; accepted 3 November 2016; published: 20 January 2017

Subject Editor: Bernard Landry.

\begin{abstract}
Water ferns (Azolla spp., Azollaceae) are reported for the first time as host plants for the larvae of the small China-mark moth Cataclysta lemnata (Linnaeus) (Lepidoptera: Crambidae: Acentropinae) in rice fields and waterways of northern Iran. Cataclysta lemnata is a semi-aquatic species that has been recorded to feed on Lemnaceae and a few other aquatic plants. However, it has not been reported before on Azolla spp. Larvae use water fern as food source and shelter and, at high population density in the laboratory, they completely wiped water fern from the water surface. Feeding was confirmed after rearing more than eight continual generations of $C$. lemnata on water fern in the laboratory. Adults obtained this way are darker and have darker fuscous markings in both sexes compared with specimens previously reported and the pattern remains unchanged after several generations.
\end{abstract}

\section{Introduction}

Cataclysta lemnata (Linnaeus) is a small semi-aquatic moth belonging to the Crambidae subfamily Acentropinae. Acentropinae, previously known as Nymphulinae, are distributed worldwide and reach their highest diversity in tropical regions of South East Asia/Malaysia and in the Neotropical Region (Mey and Speidel 2008). Until 2008, a total of 50 genera and 737 described species were assigned to this subfamily and 23 new species were described from Africa in 2012 (Mey and Speidel 2008; Agassiz 2012). Nuss et al. (2016) list 745 species in 75 genera. Most of the Acentropinae species have aquatic larvae and in some species, e.g. Parapoynx stratiotata (Linnaeus), the larvae have gills for breathing under water (Hasenfuss 1960).

The genus Cataclysta was described by Hübner, 1825 with Phalaena (Geometra) lemnata Linnaeus, as the type species. There are 18 described species assigned to this genus (Nuss et al. 2016) and the full synonymy of $C$. lemnata is given by Speidel (2005). Cataclysta lemnata is sexually dimorphic (Figs 1,2). The morphological characteristics of each sex have been described by Speidel (1984), Goater (1986), and Speidel (2005). 


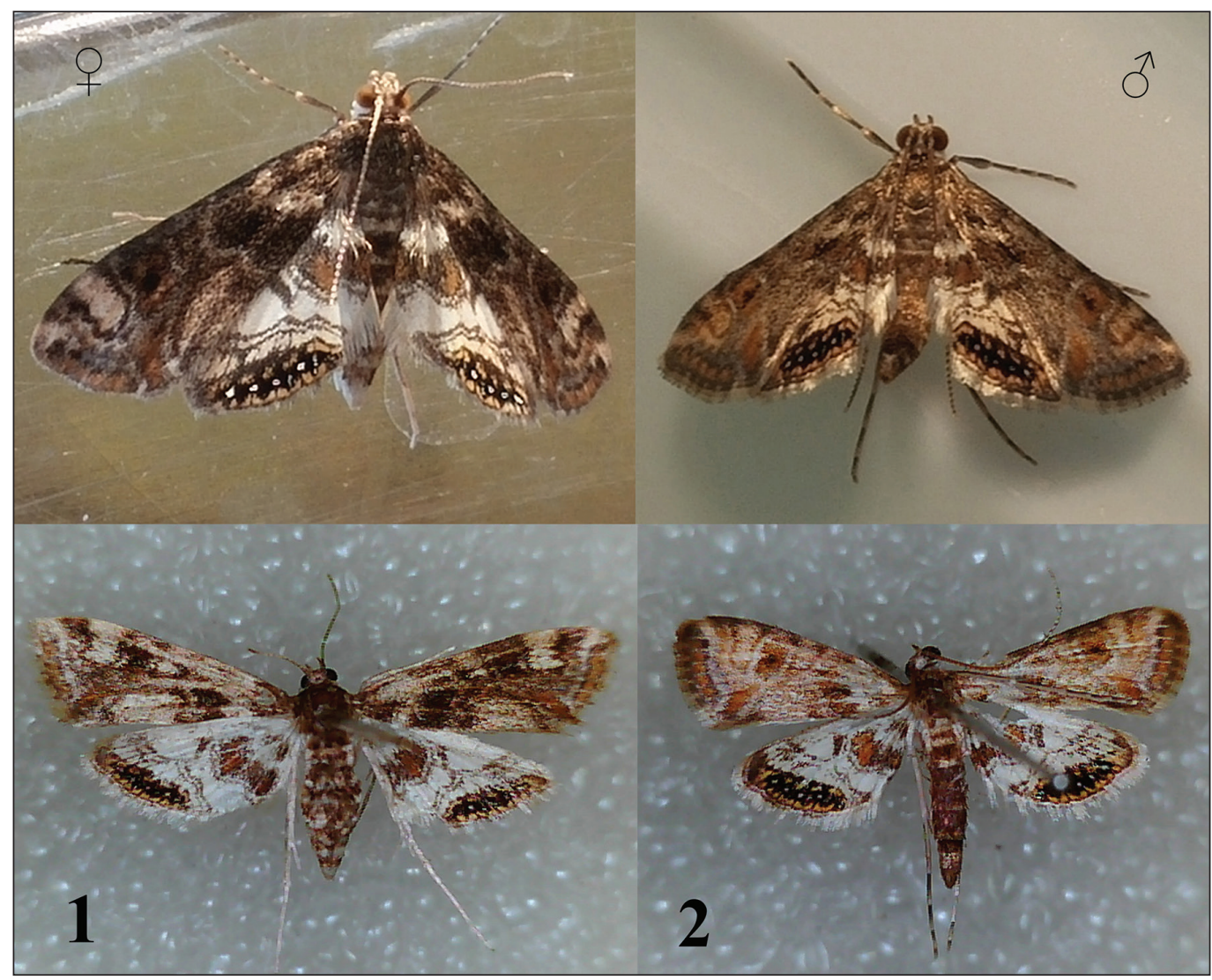

Figures 1-2. Cataclysta lemnata adults. 1. Female; 2. Male (live specimens above and prepared specimens below).

Azolla Lamarck is a genus of aquatic ferns and small-leaved floating plants divided into two subgenera: Euazolla, containing five species, and Rhizosperma with two species (Raja et al. 2012). Different species of Azolla provide various benefits such as organic nitrogen source, soil improvement and nutrient availability, weed suppression, food source for livestock, chickens, ducks and fishes (Anonymous 1987; Ferentinos et al. 2002). However, some of the species, such as Azolla filiculoides Lamarck and Azolla pinnata R. Brown (e.g. Barreto et al. 2000) are considered as major weeds in South Africa, Europe, and New Zealand (Hill 2003; Bodle 2008; Sadeghi et al. 2013a).

Azolla filiculoides is native to the tropics, subtropics, and warm temperate regions of Africa, Asia, and the Americas (Costa et al. 2009), while A. pinnata is native to a large area of the tropics, subtropics, and warm temperate regions of Africa, Asia, and Australia (Sweet and Hills 1971; PIER 2007; Pemberton and Bodle 2009). Both species, and in particular A. filiculoides, are among the world's fastest growing aquatic macrophytes, with a doubling time in biomass of only $2-5$ days (Zimmerman 1985; Taghi-Ganji et al. 2005).

In Iran, A. filiculoides is considered an alien species (JICA 2005; Delnavaz and Azimi 2009). Although the presence of another species is not yet confirmed, it seems that there is more than one Azolla species in some areas (Figs 3, 4). The Anzali and Amir-Kelayeh wetlands are two ecologi- 


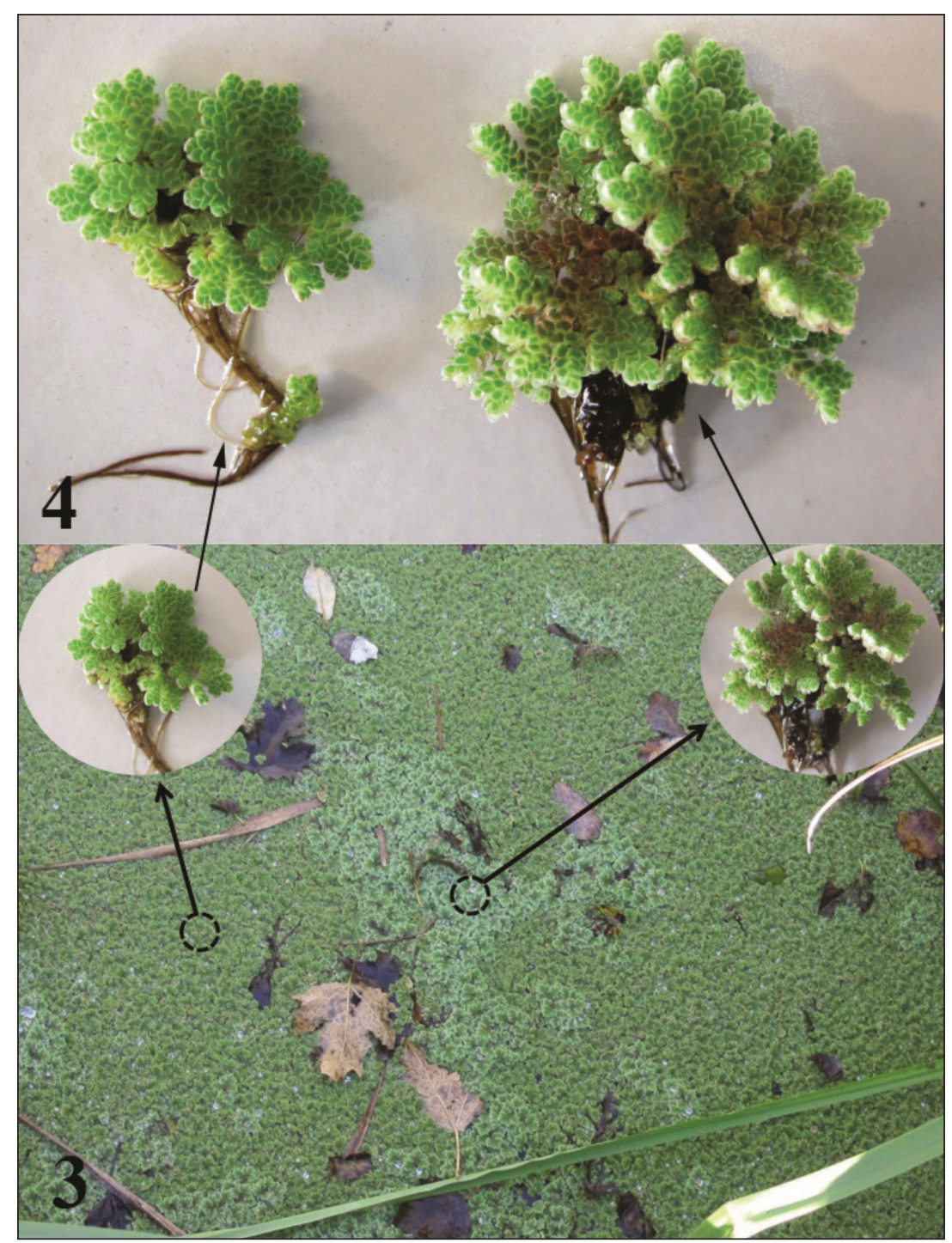

Figures 3-4. Azolla spp. in natural habitats that seem to represent different species. 3. Different coloration of Azolla spp. in natural habitats; 4 . Different size and shape of each type.

cally important natural habitats in the north of Iran for breeding, wintering, and survival of many species of birds, fishes, and micro-organisms (Khoshechin 1993; Naddafi et al. 2005; Charkhabi and Sakizadeh 2006; Moradinasab et al. 2012). The invasion of Azolla into these wetlands (Delnavaz and Azimi 2009; Sadeghi et al. 2013a) is of concern because infestations reduce the quality of the water used for agriculture and humans, and simplify local aquatic food webs (Hill 1998). In addition, in rice fields with a poor drainage system this annoying weed could become problematic in transplanting rice-culturing systems because dense masses cause seedling death by covering the young seedlings and force the farmers to transplant anew. 
Stenopelmus rufinasus Gyllenhal (Coleoptera: Curculionidae), a weevil native to the USA, has had a huge impact on A. filiculoides as a biological control agent in Africa, USA, and some other regions (Hill et al. 2008; Partt et al. 2013). However, due to the various positive and negative effects of other active herbivores on Azolla as biotic resistance factors and competitor species to the main biological agents, the identification of other active herbivores on Azolla was found to be desirable. Mechanical methods for control of water fern in Iran are impractical and there are no registered safe herbicides for aquatic ecosystems either. Therefore, control options for this obnoxious weed in Iran are limited. This situation stimulated the use of biological control as a sustainable strategy for the long-term management of Azolla spp. (Richerson and Grigarick 1967; McConnachie et al. 2003). We conducted surveys in rice fields over two years due to a lack of information on local herbivores attacking Azolla spp. in Iran, and the specific objective of this paper is to report the life history of C. lemnata attacking Azolla spp. in Iran.

\section{Material and methods}

Rearing: Laboratory colonies were established by collecting larvae and pupae from water fern

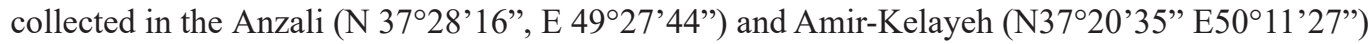
wetlands, waterways and experimental rice fields at the Rice Research Institute of Iran (RRII) (N 37²'22.2”, E 49³8'40.7’', $80 \mathrm{~m}$ ) from September to November 2014 and 2015.

Larvae and pupae were kept in transparent plastic containers ( 16.5 by $25 \mathrm{~cm}$, diameter by height) filled with $1500 \mathrm{ml}$ of water and $40 \mathrm{~g}$ of water fern. These containers were used for rearing in all tests. After adult emergence, the males and females were transferred to the mating containers. We used transparent plastic cups ( 8.5 by $11 \mathrm{~cm}$, diameter by height) filled with $200 \mathrm{ml}$ of water and $3 \mathrm{~g}$ of water fern, and covered with transparent cellophane for mating and we made small holes with a needle in the cellophane for ventilation. Two or three males with one female were released in each container to maximize the chances of fertilising eggs. Cups were changed daily until the female died. Water fern was also renewed regularly. Eggs were counted and kept in the incubator until larval emergence. First instar larvae released in rearing containers and all life stages were surveyed daily. Rearing containers were renewed every five days in order to prevent the growth of fungi and bacteria.

Identification: Forty adults were used for preliminary identification based on wing venation and other morphological characters. Dissection of both male and female genitalia (Figs 17-21) were made following the indications of Landry (2003) and Lee and Brown (2009). Dissections were conducted at the RRII laboratory and photographs sent to D. Agassiz in London for final determination.

Field observations: During 2014 and 2015, feeding damage observations by C. lemnata on water fern and other potential host plants were conducted in the waterways and experimental rice fields located at RRII.

\section{Results}

Identification: Based on dissections of both male and female genitalia, the specimens were identified as Cataclysta lemnata.

Eggs: Less than $1 \mathrm{~mm}$ in diameter, globular, opaque to white (Fig. 5), with two darker spots on fertilised eggs after 24-48 hours (Fig. 6). These spots are larval eyes that become invisible as the 


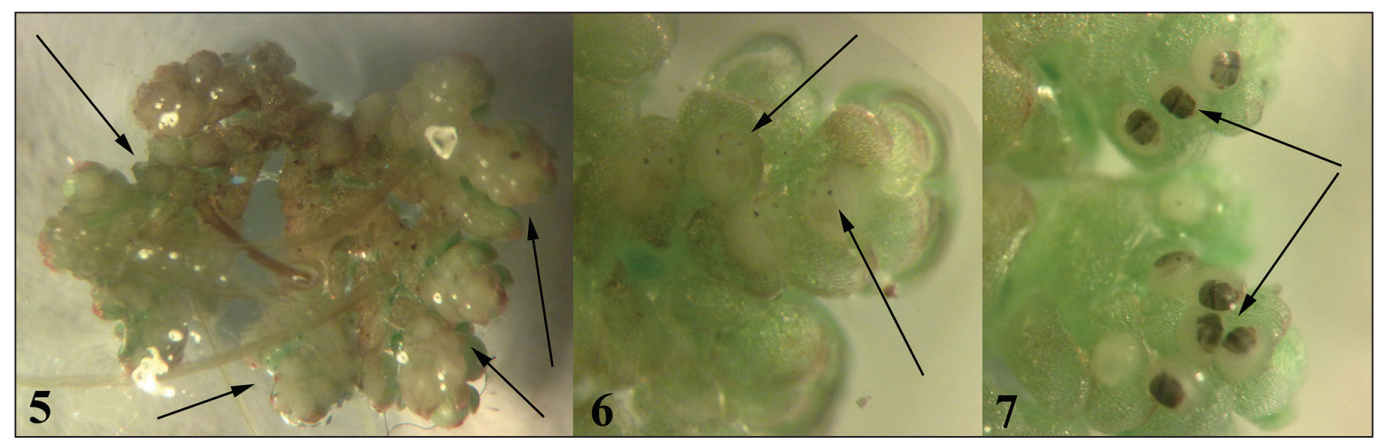

Figures 5-7. Cataclysta lemnata eggs on Azolla. 5. A few hours after laying; 6. After 48-72 hours; 7. A few hours before hatching.

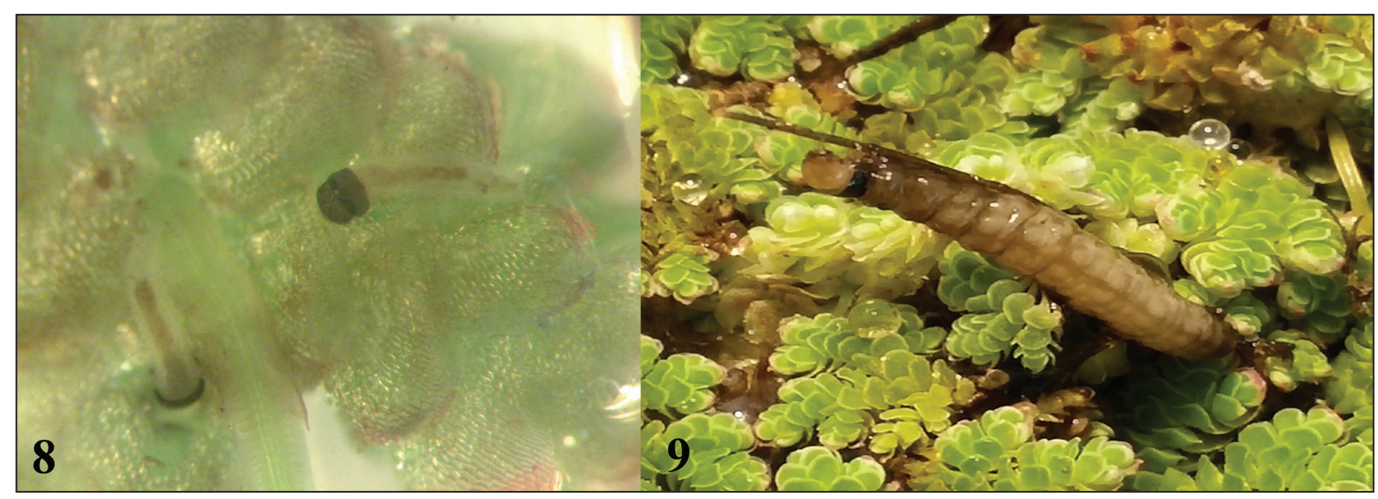

Figures 8-9. Cataclysta lemnata larvae on Azolla. 8. First instar larva; 9. Last instar larva.

head capsule gets darker. Before hatching, the head capsule becomes completely visible (Fig. 7). The eggs are laid singly or in groups of two or more under water on fern leaves. The developmental time of the eggs at $25-27^{\circ} \mathrm{C}$ was 5-7 days.

Larva: Newly hatched larvae are off-white, about $1.5 \mathrm{~mm}$ in length, with a black head capsule (Fig. 8). By the first moulting, after 3-5 days, the body colour changes to greenish grey or black and the head capsule becomes off-white. The last instar larva is dark grey to black and $15-18 \mathrm{~mm}$ in length with an off-white head capsule (Fig. 9). The developmental time of 100 larvae at $23-25^{\circ} \mathrm{C}$ was 25-47 days.

Pupa: Pupation usually occurs in shelters made from water fern leaves and a silky cover. As in other Acentropinae, the pupa of $C$. lemnata has chimney-like stigmata on abdominal segments 2 to 4. The pupa is reddish brown and approximately $7 \mathrm{~mm}$ in length (Figs 10-13). The development time of 50 pupae at $25-27^{\circ} \mathrm{C}$ was 7 days approximately.

Adults: The wingspan is $13-18 \mathrm{~mm}$ in male and $18-24 \mathrm{~mm}$ in female. Male with head and thorax light brown. Forewing off-white; costa fuscous, subbasal area with scattering of ochreous scales and dark brown patterns, discal spot with ochreous margin, median area with scattering of ochreous scales and antemedian ochreous spot, termen with a series of fuscous spots; fringe dirty yellow and brown alternately. Hindwing white with ochreous subbasal fascia, a scattering of pale fuscous scales, and one discal spot; termen with five conjoined black terminal spots, each with one 


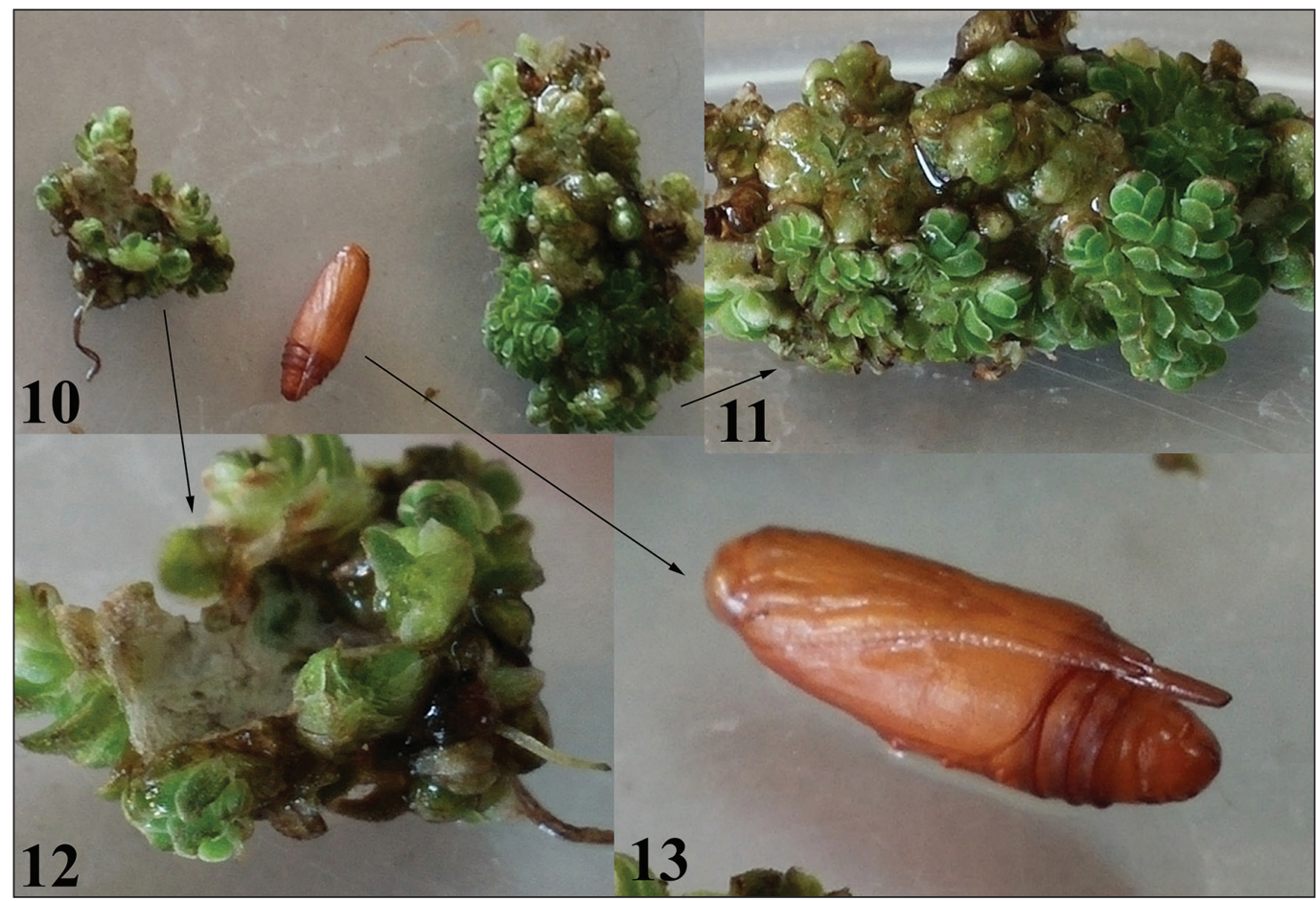

Figures 10-13. Cataclysta lemnata pupa. 10. Pupa; 11. Pupal shelter; 12. Inside the pupal shelter with a silky layer; 13. Pupa with chimney-like stigma.

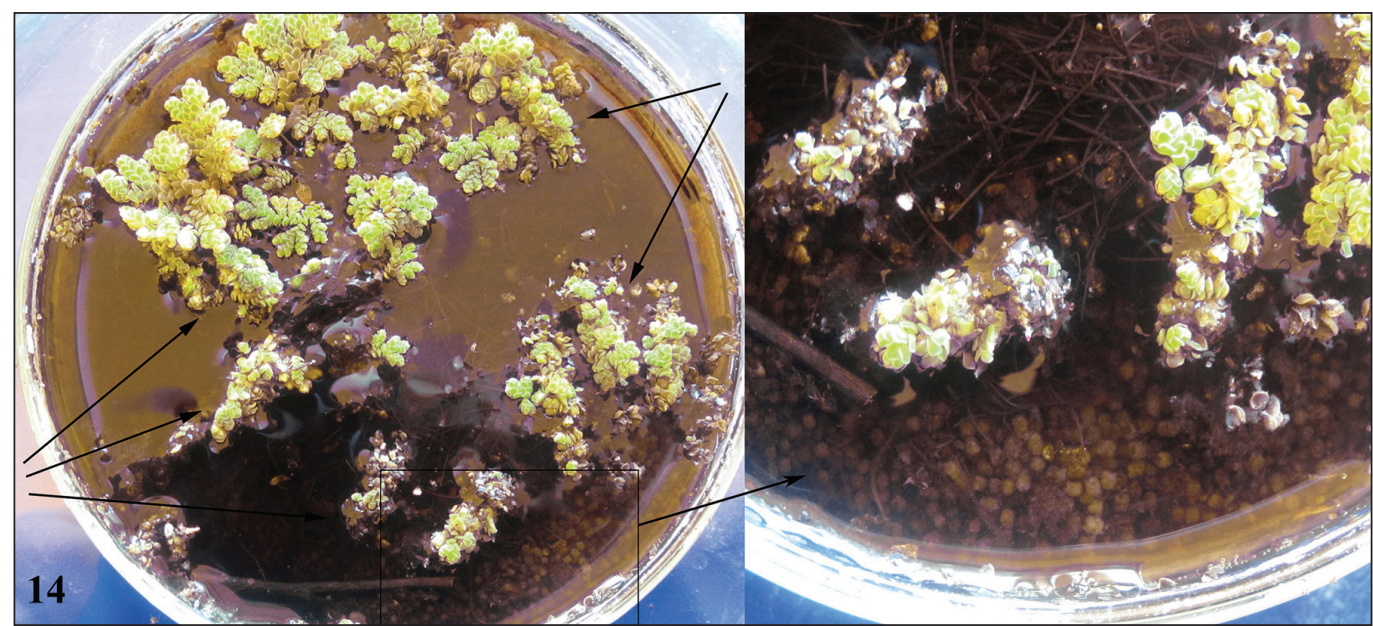

Figure 14. Evidence of Cataclysta lemnata activity. Larval shelters on surface; magnified: frass and stems at bottom of Petri dish.

silver dot; fringe white with dark line at base (Fig. 2). Female with head and thorax brown. Forewing fuscous and fringe with obscure markings as in males; hindwing as in male, with an irregular fuscous median fascia and a white lined fringe (Fig. 1). 
Evidence of damage on host plants: First instar larvae have been reported to be internal feeders on duckweed leaves (Chapman 1905; Wojtusiak and Wojtusiak 1960). However, on Azolla spp., first instar larvae feed on leaf buds, also internally. After a few days, they make shelters by attaching Azolla fronds to one another. The larvae remain in these shelters until pupation. They continue feeding and, as they develop, they make their shelters bigger. As the larvae get ready for pupation, they close the shelter with silk and adults emerge after almost a week. During heavy infestations in the laboratory, larvae almost wipe out water fern from the water surface and produce dregs made of cut stems and frass at the bottom of their containers (Fig. 14).

\section{Discussion}

The exotic aquatic fern, A. filiculoides, has invaded the Anzali Wetland. Since then, the overall ecological water quality, the habitat conditions, the numbers of migratory birds and fishes, and the aquatic plant diversity have declined in this ecosystem, particularly in the protected Selkeh wildlife refuge (Sadeghi et al. 2013a, b). In addition, the Amir-Kelayeh Wetland, which is another wildlife refuge, has become infested by this annoying weed as well (Farahpour et al. 2016). These changes are mainly related to anthropogenic activities (e.g. application of fertilizers, pesticides and herbicides in the paddy fields, and poor treatment of industrial waste in the watershed) and the invasion of A. filiculoides (JICA 2005; Ganjidoust et al. 2009; Sadeghi et al. 2013b). Moreover, although Azolla species are useful in paddy fields as an organic nitrogen source, for soil improvement, nutrient availability and weed suppression, they became problematic in fields with a poor drainage system in the northern region of Iran. At the same time, it seems that more than one species of Azolla invades aquatic ecosystems in Iran (Figs 3, 4) and this is another matter of concern. In order to manage Azolla, getting insight into biotic and abiotic factors affecting its growth in aquatic ecosystems of the north of Iran was necessary. Since 2011, some studies were conducted in the Anzali Wetland on some of the abiotic factors and the habitat requirements of $A$. filiculoides (Sadeghi et al. 2012a, b; 2013a, b). However, this weed's biotic resistance factors in Iran remained unclear.

During the present study, we investigated the activity of C. lemnata on Azolla spp. in rice fields and waterways. The first studies on $C$. lemnata suggested that this moth is a stenophagous species on Lemnaceae (Chapman 1905; Wojtusiak and Wojtusiak 1960) but it was reported later that this moth consumes various macrophytes (Vander Velde 1979, 1988; Pabis 2014). Cataclysta lemnata has been previously recorded from Iran (Speidel 2005), but Azolla spp. were never mentioned before as an element of the C. lemnata diet; in previous reports this species did not attack most other macrophytes beside Lemnaceae whilst the plants were fresh (Vander Velde 1979, 1988). In the rice fields and waterways of Iran, the moth is active from May until November. If the winter is mild, the larvae continue their activity slowly. They attack fresh water fern leaves and stems, but it seems that they prefer leaves to stems (Fig. 14). In the laboratory, larvae were capable of removing large parts of the floating cover of water ferns in Petri dish tests (Fig. 15) and when we increased the population density of larvae they almost wiped out the floating cover (Fig. 16).

Speidel $(1984,2005)$ and Goater (1986) described and illustrated C. lemnata with a wingspan of $18-19 \mathrm{~mm}$ in the male and $22-24 \mathrm{~mm}$ in the female. The characteristics of the Iranian specimens are very similar to those mentioned in Speidel $(1984,2005)$ and Goater (1986), except that the Iranian specimens differ in the colouration of the head and thorax, the ochreous markings of the 


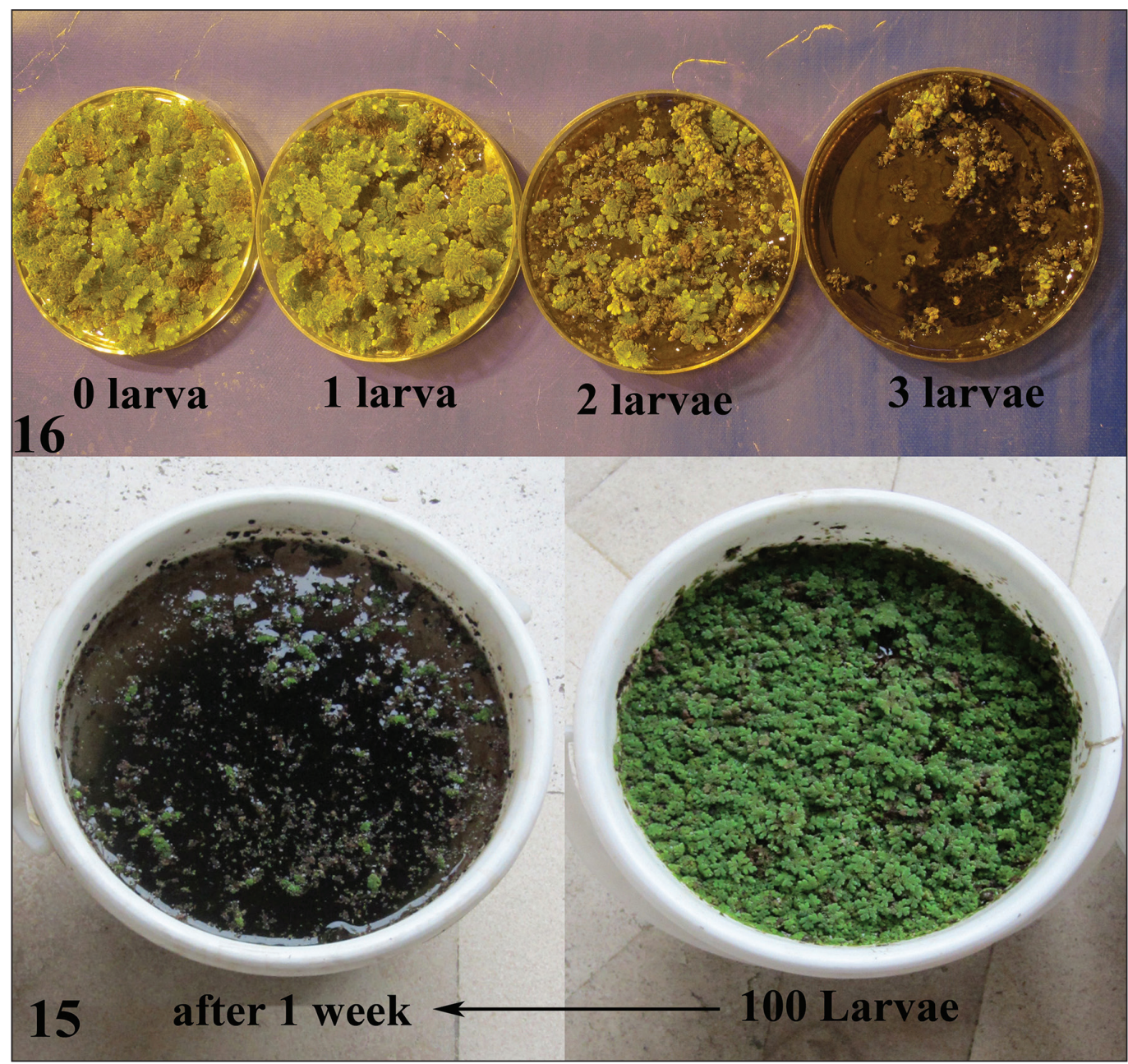

Figs 15-16. Cataclysta lemnata effects on water fern in the laboratory tests. 15. Petri dish test with different population density; 16. Larvae consuming the floating layer during a week of artificial infestation with highdensity larval population in laboratory.

forewing, and the ochreous subbasal fascia of the hind wing. These differences are visible in both sexes, but they are more prominent in males.

The explanation for these external differences is unclear. Dissections of genitalia (Figs 17-21) showed that our specimens do not differ in that respect from those of other populations of C. lemnata occurring outside of Iran. It is possible that some of the differences among populations are due to phenotypic plasticity. There are many environmental conditions (e.g. temperature, diet, parasitism, etc.), that induce phenotypic plasticity in insects. For example, woolly bear caterpillars (Grammia incorrupta Edwards; Lepidoptera, Erebidae, Arctiinae) that were parasitized by Exorista mella Walker (Diptera, Tachinidae) ingest more of the plant toxins called pyrrolizidine alkaloids to confer increased resistance against parasitoids (Singer et al. 2009). Chilo suppressalis (Walker) (Crambidae, Crambinae) that feed on water-oat differ in adult body size and mating time compared with those that feed on 


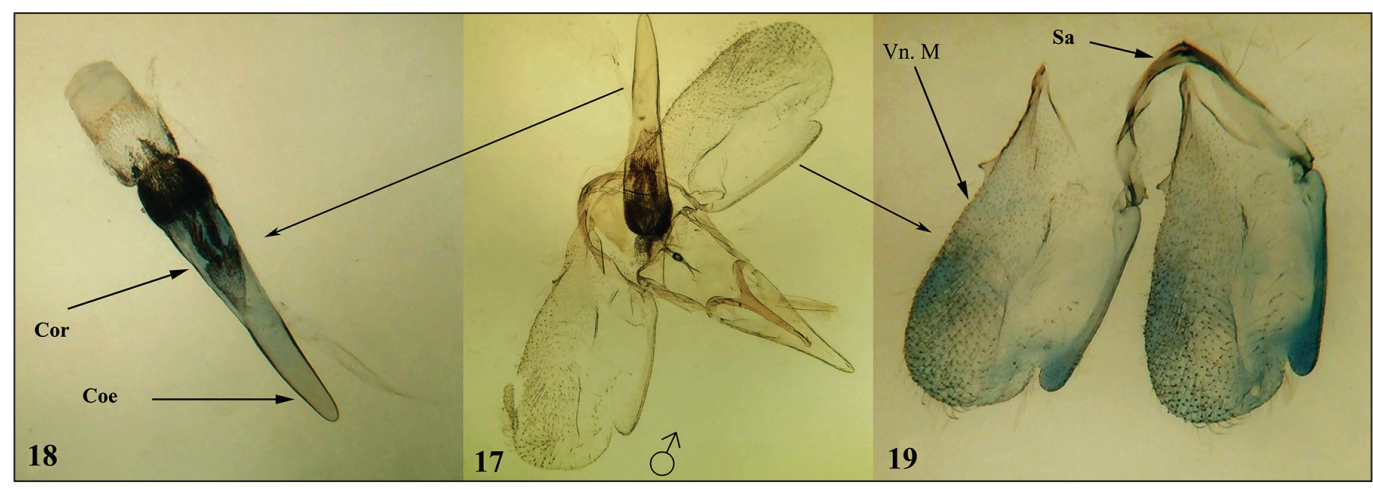

Figures 17-19. Cataclysta lemnata male genitalia slides. 17. Ventral view with phallus; 18. Phallus; 19. Valva; Cor - cornuti; Coe - coecum; Vn. $\mathbf{M}$ - ventral margin; Sa - sacculus)

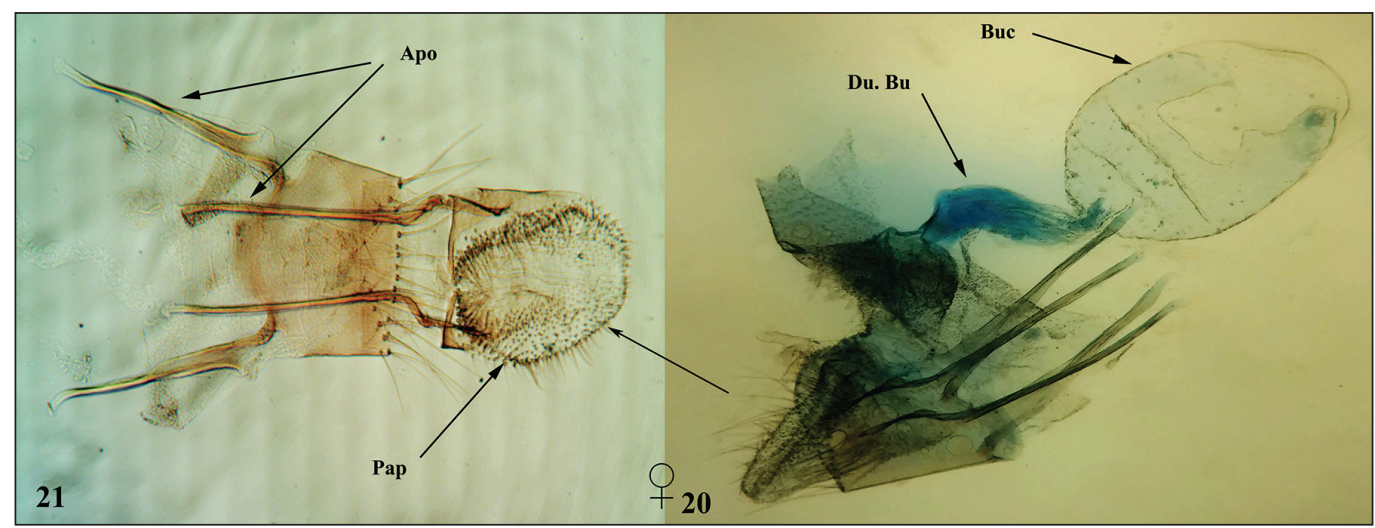

Figures 20-21. Cataclysta lemnata female genitalia. 20. Lateral view; 21. Last segments of the abdomen. Buc - bursa copulatrix; Du. Bc - ductus bursae; Apo - apophyses; Pap - papillae.

rice (Takasaki et al. 1969; Ishiguro et al. 2006). Perhaps the different colouration of $C$. lemnata feeding on Azolla spp. in Iran represents phenotypic plasticity related to a different diet. Nevertheless, we reared larvae on both Azolla spp. and Lemna minor as main host plants separately and imagines from both diets were phenotypically the same. Since this type of colouration is permanent among generations, it is possible that these specimens represent a new biotype of $C$. lemnata or perhaps even a new subspecies. However, we do not have any molecular or other evidence to test this hypothesis yet.

Our study is the first to record Azolla sp. as a host plant for C. lemnata. However, there are 12 other recorded Pyraloidea that feed on Azolla spp.: Elophila enixalis Swinhoe, E. nigralbalis Caradja, E. responsalis Walker, E. turbata Butler, E. melagynalis Agassiz, E. manilensis Hampson (Mochida et al. 1985, 1987), E. africalis Hampson (Roberts et al. 1998) and Synclita obliteralis Walker (Habeck 1991) in Acentropinae, Ephestiopsis vishnu Roesler and Kuppers (Mochida et al. 1985, 1987) and Cryptoblabes gnidiella Millière (Sasmal and Kulshreshtha 1984) in Phycitinae, and Samea multiplicalis Guenée (Knopf 1976) and Diasemiopsis ramburialis Duponchel (Farahpour et al. 2016) in Spilomelinae. 
Although we briefly studied the biology of $C$. lemnata as a probable biotic resistance factor for water fern, many other important biological aspects such as population growth parameters and host preference in the natural habitat remain unclear. We could not find any specific parasitoid or predator for this moth although there are several generalist predators and parasitoids active in the rice fields (Shepard et al. 1987; Ooi and Shepard 1994) that could affect C. lemnata populations. However, some of the imagines in our colonies had a wing growth abnormality that seems to be genetic in origin. These imagines have distorted wings and were unable to fly properly, but they could mate as well as other imagines and produce fertile eggs. We did not use statistical or molecular methods for this study, but the number of eggs produced by these imagines was lower than for normal imagines. This abnormality appeared after at least four to five continual generations in the laboratory and only one or two imagines showed this abnormality during a whole generation.

\section{Conclusion}

Many studies have mentioned Azolla spp. as a weed (Hill 2003; Bodle 2008; Delnavaz and Azimi 2009). These invasive aquatic ferns are a major concern for biologists and ecologists dealing with conservation and management of wetland ecosystems due to the threats they may pose to the rich original biological diversity. They can have important harmful and irreversible impacts on wetlands as they may change the local fauna and flora (Sax et al. 2005; Vander Zanden and Olden 2008). Over the last few years, this obnoxious weed has invaded many wetlands in northern Iran (JICA 2005; Delnavaz and Azimi 2009; sadeghi et al. 2012a, b; 2013a, b). Due to the invasiveness of Azola spp., many native macrophytes such as duckweed have been eradicated in these valuable habitats (Sadeghi et al. 2012a). Cataclysta lemnata is an aquatic moth that was originally reported to feed on duckweeds and a few of other macrophytes. However, probably because of the eradication of its main host plant in many aquatic ecosystems of the northern region of Iran, this moth attacks exotic Azolla spp. water ferns and chooses them as new host plants. The effect of this moth on water fern as a biotic resistance factor is not clear yet and despite a rich fauna of aquatic and semi-aquatic insects, other biotic resistance factors of water fern in Iran are still poorly known. We have started our surveys on water fern biotic resistance factors in the rice fields and wetlands in the north of Iran in 2013 and this is the second report of our results. More studies are under way to uncover important facts on the biotic resistance factors of this annoying weed in northern regions of Iran.

\section{Acknowledgements}

We would like to thank Dr. Rodrigo Diaz, Assistant Professor of Entomology at Louisiana State University (Baton Rouge), for his advice and review of the manuscript, the University of Mohaghegh Ardabili and Rice Research Institute of Iran (RRII) for providing financial support, and anonymous reviewers for their comments.

\section{References}

Agassiz DJ (2012) The Acentropinae (Lepidoptera: Pyraloidea: Crambidae) of Africa. Zootaxa 3494: 1-73. Anonymous (1987) Azolla utilization. Proceedings of the Workshop on Azolla Use, International Rice Research Institute, Philippine. 
Barreto R, Charudattan A, Pomella A, Hanada R (2000) Biological control of Neotropical aquatic weeds with fungi. Crop Protection 19: 697-703. https://doi.org/10.1016/S0261-2194(00)00093-4

Bodle M (2008) Feathered mosquito fern (A. pinnata R. Br.) comes to Florida. Aquatics 30: 4-8.

Chapman TA (1905) The earlier stages of Cataclysta lemnata L. The Entomologist 37: 1-5.

Charkhabi AH, Sakizadeh M (2006) Assessment of spatial variation of water quality parameters in the most polluted branch of the Anzali Wetland, Northern Iran. Polish Journal of Environmental Studies 15(3): 395-403.

Costa ML Santos MCR, Carrapico F, Pereirac AL (2009) Azolla-Anabaena's behaviour in urban wastewater and artificial media-Influence of combined nitrogen. Water Resource 43: 3743-3750. https://doi. org/10.1016/j.watres.2009.05.038

Delnavaz-Hashemloian B, Ataei-Azimi A (2009) Alien and exotic Azolla in northern Iran. African Journal of Biotechnology 8: 187-190.

Farahpour-Hghani A, Jalaeian M, Landry B (2016) Diasemiopsis ramburialis (Duponchel) (Pyralidae s. 1., Spilomelinae) in Iran: first record for the country and first host plant report on water fern (Azolla filiculoides Lam., Azollaceae). Nota lepidopterologica 39(1) 2016: 1-11. https://doi.org/10.3897/nl.39.6887

Ferentinos L, Smith J, Valenzuela H (2002) Azolla, Green manure crop. Sustainable agriculture in Hawaii. University of Hawaii, Manoa, 3 pp.

Ganjidoust H, Ayati B, Khara H, Khodaparast SH, Akbarzadeh A, Ahmadzadeh LT, Nezami ShA, Zolfinezhad K (2009) Investigation of environmental pollution in Shiah Keshim Wetland. Environmental Sciences 3: 117-122.

Goater B (1986) British pyralid moths: A guide to their identification. Harley Books, 175 pp.

Habeck DH (1991) Synclita obliteralis (Walker), the Waterlily Leafcutter:(Lepidoptera: Pyralidae: Nymphulinae). Florida Department of Agriculture and Consumer Services, Division of Plant Industry, Gainesville Florida, United States of America.

Hasenfuss I (1960) Die larval systematik der zünsler (Pyralidae). Akademie-Verlag, Berlin.

Hill MP (1998) Life history and laboratory host range of Stenopelmus rufinasus Gyllenhal (Coleoptera: Curculionidae) a natural enemy for Azolla filiculoides Lamarck (Azollaceae), in South Africa. Biological Control 43: 215-224.

Hill MP (2003) The impact and control of alien aquatic vegetation in South African aquatic ecosystems. African Journal of Aquatic Science 28: 19-24. https://doi.org/10.2989/16085914.2003.9626595

Hill MP, McConnachie AJ, Byrne MJ (2008) Azolla filiculoides Lamarck (Pteridophyta: Azollaceae) control in South Africa: A10-year review. In: Julien MH, Sforza R, Bon MC, Evans HC, Hatcher PE, Hinz HL and Rector BG (Eds) Proceedings of the XII International Symposium on Biological Control of Weeds. CAB International, 558-560. https://doi.org/10.1079/9781845935061.0558

Ishiguro N, Yoshida K, Tsuchida K (2006) Genetic differences between rice and water-oat feeders in the rice stem borer, Chilo suppressalis (Walker)(Lepidoptera: Crambidae). Applied Entomology and Zoology 41(4): 585-593. https://doi.org/10.1303/aez.2006.585

JICA (Japan International Cooperation Agency) (2005) The study on integrated management of Anzali Wetland in the Islamic Republic of Iran, Final report 2.

Khoshechin M (1993) Monthly bio status of plant and birds of Guilan province wetlands. DOE (Department of Environment), Iran.

Knopf K, Habeck D (1976) Life history and biology of Samea multiplicalis. Environmental Entomology 5(3): 539-542. https://doi.org/10.1093/ee/5.3.539

Landry B (2003) Méthode de préparation des génitalia de papillons. http://www.ville-ge.ch/mhng/dpt_ento_ rech.php [accessed 31.viii.2015]

Lee S, Brown RL (2009) Preparing dissections and slide mounts of moths, including wing venation, genitalia, and whole bodies. http://mississippientomologicalmuseum.org.msstate.edu/Researchtaxapages/CactusMoths/Methodology.html [Accessed 31.viii.2015] 
McConnachie AJ, de Wit MP, Hill MP, Byrne MJ (2003) Economic evaluation of the successful biological control of Azolla filiculoides in South Africa. Biological Control 28: 25-32. https://doi.org/10.1016/ S1049-9644(03)00056-2

Mey W, Speidel W (2008) Global diversity of butterflies (Lepidotera) in freshwater. Hydrobiologia 595(1): 521-528. https://doi.org/10.1007/s10750-007-9038-9

Mochida O, Yoshiyasu Y, Dimaano D (1985) Taxonomic and biological studies on pyralid moths on azolla (Lepidoptera). IRRI Saturday Seminar, Los Banos, Laguna (Philippines), Mar 1985.

Mochida O, Yoshiyasu Y, Dimaano D (1987) Insect pests of Azolla in the Philippines. Workshop on Azolla Use, Fuzhou, Fujian (China).

Moradinasab Gh, Daliri M, Ghorbani R, Paighambari SY, Davoodi R (2012) Length-weight and length-length relationships, relative condition factor and Fulton's condition factor of five Cyprinid species in Anzali wetland, southwest of the Caspian Sea. Caspian Journal of Environmental Sciences 10(1): 25-31.

Naddafi R, Abdoli A, Hassanzadeh-Kiabi B, Mojazi-Amiri B, Karami M (2005) Age, growth and reproduction of the Caspian roach (Rutilus rutilus caspicus) in the Anzali and Gomishan wetlands, North Iran. Journal of Applied Ichthyology 21: 492-497. https://doi.org/10.1111/j.1439-0426.2005.00669.x

Nuss M, Landry B, Mally R, Vegliante F, Tränkner A, Bauer F, Hayden J, Segerer A, Schouten R, Li H, Trofimova T, Solis MA, De Prins J, Speidel W (2016) Global Information System on Pyraloidea. http://www.pyraloidea.org Ooi PAC, Shepard BM (1994) Predators and parasitoids of rice insects. In: Heinrichs EA(Ed.) Biology and Management of Rice Insects. Wiley Eastern Ltd., India and IRRI, Manila, Philippines, 613-656.

Pabis K (2014) Life cycle, host plants and abundance of caterpillars of the aquatic moth Cataclysta lemnata (Lepidoptera: Crambidae) in the post-glacial lake in central Poland. North-Western Journal of Zoology 10(2): 441-444.

Partt CF, Shaw RH, Tanner RA, Dejeddour DH, Vos JGM (2013) Biological control of invasive non-native weeds: An opportunity not to be ignored. Bulletin of Entomological Research 73(4): 144-154.

Pemberton RW, Bodle JM (2009) Native North American Azolla Weevil, Stenopelmus rufinasus (Coleoptera: Curculionidae), Uses the Invasive Old World Azolla pinnata as a Host Plant. Florida Entomologist 92(1):153-155. http://dx.doi.org/10.1653/024.092.0124

PIER (2007) Pacific Islands Ecosystems at Risk. Species list, Azolla pinnata. Accessed June 15, 2008 from http:// www.hear.org/pier/species/azolla_pinnata.htmR.

Raja W, Rathaur P, John SA, Ramteke PW (2012) Azolla-Anabaena association and its significance in supportable agriculture. Hacettepe Journal of Biology and Chemistry 40(1): 1-6.

Richerson PJ, Grigarick AA (1967) The life history of Stenopelmus rufinasus (Coleoptera: Curculionidae). Annals of the Entomological Society of America 60: 51-354. https://doi.org/10.1093/aesa/60.2.351

Roberts JMF, Hance Th, Hove Cv (1998) Fecundity and ovipositional preference of Elophila africalis on Azolla: test for host plant susceptibility. African Zoology 112(3): 215-222.

Sadeghi R, Zarkami R, Sabetraftar K, Van Damme P (2012a) Application of classification trees to model the distribution pattern of a new exotic species Azolla filiculoides (Lam.) at Selkeh Wildlife Refuge, Anzali wetland, Iran. Ecological Modelling 243: 8-17. https://doi.org/10.1016/j.ecolmodel.2012.06.011

Sadeghi R, Zarkami R, Sabetraftar K, Van Damme P (2012b) Use of support vector machines (SVMs) to predict distribution of an invasive water fern Azolla filiculoides (Lam.) in Anzali wetland, southern Caspian Sea, Iran. Ecological Modelling 244: 117-126. https://doi.org/10.1016/j.ecolmodel.2012.06.029

Sadeghi R, Zarkami R, Sabetraftar K, Van Damme P (2013a) A review of some ecological factors affecting the growth of Azolla spp. Caspian Journal of Environmental Sciences 11(1): 65-76.

Sadeghi R, Zarkami R, Sabetraftar K, Van Damme P (2013b) Application of genetic algorithm and greedy stepwise to select input variables in classification tree models for the prediction of habitat requirements of Azolla filiculoides (Lam.) in Anzali wetland, Iran. Ecological Modelling 251: 44-53. https://doi. org/10.1016/j.ecolmodel.2012.12.010 
Sasmal N, Kulshreshtha J (1984) Cryptoblabes gnidiella (Mill.), a pest of 'Azolla'infests rice. Rice Research Newsletter 5(1-2): 2.

Sax DF, Brown JH, White EP, Gaines SD (2005) Dynamics of species invasions: Insights into the mechanisms that limit species diversity, 447-465.

Shepard BM, Barrion AT, Litsinger JA (1987) Friends of the rice farmer: Helpful insects, spiders and pathogens. International Rice Research Institute, Los Banos, Philippines.

Singer MS, Mace KC, Bernays EA (2009) Self-medication as adaptive plasticity: increased ingestion of plant toxins by parasitized caterpillars. Plos One 4(3): e4796. https://doi.org/10.1371/journal.pone.0004796

Speidel W (1984) Revision der Acentropinae des palaearktischen Faunengebietes: (Lepidoptera, Crambidae), 80 Abb.,3 Taf. Neue entomologische Mitteilungen 12: 1-157.

Speidel W (2005) Acentropinae. In: Goater B, Nuss M, Speidel W (Eds) Pyraloidea I (Crambidae: Acentropinae, Evergestinae, Heliothelinae, Schoenobiinae, Scopariinae). Microlepidoptera of Europe 4, 1-304.

Sweet A, Hills IV (1971) A study of Azolla pinnata Brown. American Fern Journal 71: 1-13. https://doi. org/10.2307/1546281

Taghi-Ganji M, Khosravi M, Rakhshaee R (2005) Biosorption of Pb ( $\left.{ }^{2} \mathrm{I}\right), \mathrm{Cd}\left({ }^{2} \mathrm{I}\right), \mathrm{Cu}\left({ }^{2} \mathrm{I}\right)$ and $\mathrm{Zn}$ (II) from the wastewater by treated $A$. filiculoides with $\mathrm{H} 2 \mathrm{O} 2 / \mathrm{MgCl} 2$. International Journal of Environmental Science and Technology 1: 265-271. https://doi.org/10.1007/BF03325841

Takasaki T, Noda M, Murata Z (1969) Ecology of rice stem borer moth, Chilo suppressalis Walker. I. Seasonal prevalence of rice stem borer moth feeding on the water oats. Proceeding of the Kyushu association Plant Protection 15: 118-121. https://doi.org/10.4241/kyubyochu.15.118

Van der Velde G (1979) Nymphoides peltata (Gmel.) O. Kuntze (Menyanthaceae) as a food plant for Cataclysta lemnata L. (Lepidoptera, pyralidae). Aquatic Botany 7: 301-304. https://doi.org/10.1016/03043770(79)90030-5

Van Der Velde G (1988) Cataclysta lemnata L. (Lepidoptera, Pyralidae) can survive for several years consuming macrophytes other than Lemnaceae. Aquatic Botany 31(1): 183-189. https://doi.org/10.1016/03043770(88)90048-4

Vander Zanden MJ, Olden JD (2008) A management framework for preventing the secondary spread of aquatic invasive species. Canadian Journal of Fisheries and Aquatic Sciences 65(7): 1512-1522. https://doi. org/10.1139/F08-099

Wojtusiak H, Wojtusiak RJ (1960) Biologia, występowanie I użytkowność motyli wodnych z podrodziny Hydrocampinae w stawach doświadczalnych PAN Ochaby. Polish Archives of Hydrobiology 8: 253-260.

Zimmerman WJ (1985) Biomass and pigment production in three isolates of Azolla II. response to light and temperature stress. Annals of Botany 56: 701-709. 